Mem. Inst. Oswaldo Cruz, Rio de Janeiro, Vol. 76(4) :393-396, out./dez. 1981

\title{
MARITREMOPSIS MARIETTAVOGEAE SP. N. (TREMATODA, MICROPHALLIDAE) AND AMPHIMERUS LANCEA (DIESING, 1850) (TREMATODA, OPISTHORCHIIDAE) PARASITES OF NECTOMYS SOUAMIPES (RODENTIA) IN BRAZIL
}

\author{
ANNA KOHN* \\ BERENICE M. M. FERNANDES* \\ R. MAGALHĀES PINTO* \\ DALVA A. MELLO**
}

In this paper two species of trematodes recovered from Nectomys squamipes from Goiás State, Brazil, are presented. Maritremopsis mariettavogeae sp. n. is compared to M. prolixum (Caballero \& Montero-Gei, 1961) and M. belopolskaiae (Caballero, 1964). Amphimerus lancea originally described from a cetacean host, is for the first time referred in a rodent.

Studying the parasites of mammals from Goiás State, the authors present here the results obtained after the examination of the trematodes recovered from Nectomys squamipes. Of 14 host specimens examined, one was parasitized by Maritremopsis mariettavogeae sp. $\mathrm{n}$. and another by Amphimerus lancea (Diesing, 1850). All trematodes were fixed in 5 per cent formalin without compression, stained in alcoholic-cloridric carmine and mounted in balsam. All measurements are in millimeters.

\section{Maritremopsis mariettavogeae sp. n.}

(Figs. 2-4)

\section{Description}

Small trematodes, body pyriform 0.37 to 0.46 length by 0.25 to 0.33 maximum width. Tegument without spines. Oral sucker subterminal 0.030 to 0.047 long by 0.032 to 0.050 wide. Acetabulum slightly muscular preequatorial 0.032 to 0.053 long by 0.033 to 0.045 wide. Sucker ratio 1.09 to $1: 1.1$. Short prepharynx muscular. Pharynx well developed, 0.023 to 0.036 by 0.030 to 0.043 wide. Esophagus indistinct. Caeca short, divergent, in front of cirrus sac. To the rigth side of the acetabulum there is a very large saccular structure which seems to be a genital atrium, 0.10 to 0.14 long by 0.048 to

\footnotetext{
* Instituto Oswaldo Cruz - Caixa Postal 926 - 20000 Rio de Janeiro, Brasil.

* Faculdade de Ciências da Saúde, Universidade de Brasília.

Received for publication July 15 th and accepted August 20th, 1981.
} 
0.059 wide, with a sucker-like pore, 0.026 to 0.035 by 0.028 to 0.040 wide not easily seen because of the eggs (Fig. 4). Testes round or oval, port-acetabular, placed in lateral fields, on opposite sides of the body, 0045 to 0.072 long by 0.054 to 0.096 wide, obliterated by the eggs. Cirrus sac well developed $0.16-0.21$ length by $0.050-0.063$ maximum width, situated transversally, between caeca and acetabulum, may overlap acetabular zone; contains seminal vesicle sacular, followed by a sinuous duct, very few prostatic cells (seen in sections), "pars prostatica" striated and cirrus not spined. Ovary smooth, round or oval, median or submedian, partially located in posterior acetabular area, 0.048 to 0.072 long by 0.041 to 0.072 wide. Seminal receptacle, Mehlis gland, and Laurer canal not seen. Vitellaria dorsal, with large follicles irregular in size and shape and situated transversally in the midline of the body, partially surrounding the testes. Vitelloduct confluent in the middle region of the body. Uterus occupies the entire post acetabular region, sometimes reaching the posterior end of caeca, practically obliterating from view all structures posterior to acetabulum. Eggs operculated, 0.016 to 0.023 long by 0.009 to 0.012 wide.

Material: Measurements based on 12 of 42 adult gravid specimens studied.

Host: Nectomys squamipes (Brants).

Habitat: Intestine.

Locality: Formosa, Goiás, Brazil.

Holotype no 31.877 a and paratypes no $31.877 \mathrm{~b}-\mathrm{q}$. deposited in the Helminth Collection of the Oswaldo Cruz Institute.

\section{DISCUSSION} diagnosis:

The genus Maritremopsis was erected by Deblock in 1973 with the following

"Même définition que le genre Maritrema Nicoll, 1907, notamment en ce qui concerne l'extension de l'utérus (toujours post-caecal), mais à l'exception des caractères concernant la conformation et la disposition des glandes vitellogènes composées d'un nombre de follicules restreint (de 5 à 10 environ), chacun d'une taille relativement volumineuse, et disposés linéairement en deux groupes situés essentiellement en avant de chacun des testicules; ils peuvent aussi s'étendre le long du contour externe de ces deux glandes. Vitelloductes transverses à insertion terminale, courts ou très courts."

This genus encloses the following species: $M$. ammospizae (Hunter \& Vernberg, 1953) (type species); M. ablephari (Canaris, 1971); M. belopolskaiae (Caballero, 1964); $M$. dathei (Odening, 1963); M. longibursatus (Caballero \& Brenes, 1964) and M. prolixum (Caballero \& Montero-Gei, 1961).

Maritremopsis mariettavogeae sp. n. most closely resembles $M$. prolixum and $M$. belopolskaiae differing from them by the spineless tegument, size and shape of the cirrus sac and seminal vesicle and by the presence of a saccular genital atrium. This new species is denominated after Dr. Marietta Voge from University of California, Los Angeles.

\section{Amphimerus lancea (Diesing, 1850)}

(Fig. 1)

The original description of $A$. lancea was based on trematodes recovered from Sotalia pallida $(=$ Delphinus tacushi, $=$ Sotalia tucuxi $)$ in Brazil. This species has been also referred for Orcella brevirostris and in Pica pica (Yamagutti, 1971). Its occurrence in a rodent host is described for the first time. As this species was well described by Price (1932), only the main measurement will be given, based on seven mature specimens, not compressed, although 31 worms in different stages of development were recovered. 


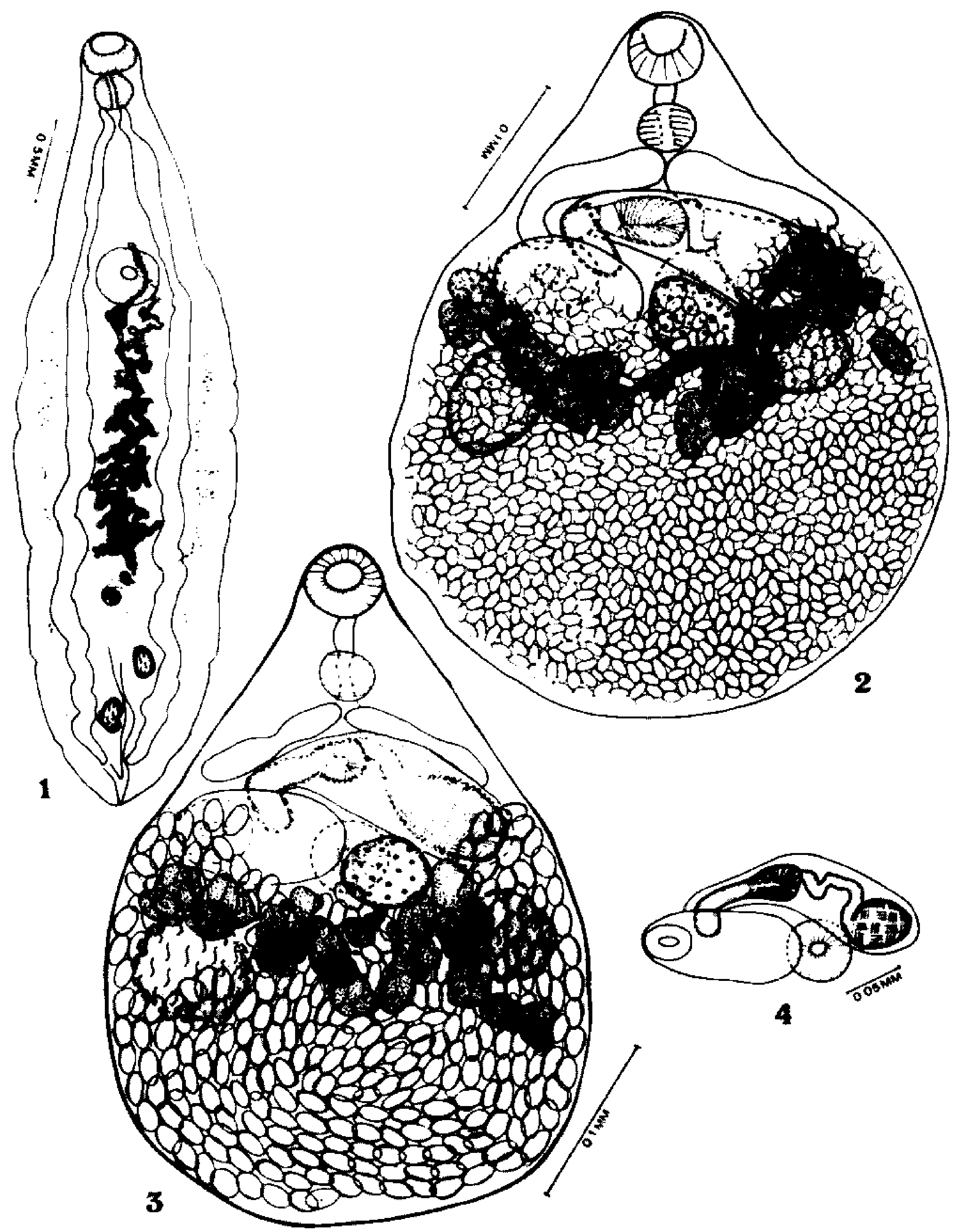

Fig. 1 Amphimerus lancea (Diesing, 1850), total, original (No. $31.878 \mathrm{c}$ ), ventral view.

IFigs. 2-4 - Maritremopsis mariettavogeae sp. n. - Fig. 2: total, (holotype, No 31.877 a); Fig. 3: paratype $N^{\circ} 31.877$ b showing another aspect of the arrangement of vitellaria; Fig. 4 : cirrus sac, genital atrium and acetabulum (paratype No 31.877 q); Figs. $2-4$ dorsal view. 
Body $3.74-4.86$ long by $1.08-1.62$ wide. Oral sucker $0.20-0.28$ long by $0.24-0.33$ wide. Pharynx $0.19-0.24$ long by $0.17-0.22$ wide. Esophagus $0.08-0.14$ in length. Acetabulum $0.31-0.39$ in diameter. Anterior testes $0.13-0.21$ long by $0.11-$ 0.19 wide. Posterior testes $0.17-0.23$ long by $0.10-0.16$ wide. Ovary $0.065-0.093$ long by $0.047-0.084$ wide. Seminal receptacle $0.10-0.20$ long by $0.06-0.13$ wide. Eggs $0.022-0.034$ long by $0.015-0.019$ wide.

Host: Nectomys squamipes (Brants).

Habitat: Liver.

Locality: Formosa, Goiás State, Brazil.

Specimes deposited in the Helminth Collection of the Oswaldo Cruz Institute n? $31.878 \mathrm{a}-\mathrm{c}$.

\section{RESUMO}

No presente trabalho sto descritas duas espécies de trematódeos parasitas de Nectomys squamipes (Brants) do Estado de Goiás: Maritremopsis mariettavogeae sp. n. e Amphimerus lancea (Diesing, 1850) parasita de bôto, é pela primeira vez referida em roedor.

\section{AKNOWLEDGEMENTS}

The authors wish to thank Dr. Guilhermina Caballero Rodríguez, Instituto de Biologia, México, for lending specimens of Maritrema prolixum to be examined.

\section{REFERENCES}

CABALlero, y C. E., 1964. Tres nuevas species de Trematoda Rudolphi, 1808 que parasitan a murcielagos (Chiroptera Blumenbach, 1774) de America Latina. Cuad. Inst. Invest. Cient. Univ. Nuevo Leon, $5: 1-34$.

CABALlERO, y C. E. \& BRENES, R. R. M., 1964. Descripción de una especie de Ornithotrema Caballero, Brenes et Arroy, 1963 y creación de una nueva subfamilia de Microphallidae Travassos, 1921 (Trematoda, Digenea). Rev. Biol Trop.. 12 :229-235.

CABALLERO. y C. E. \& MONTERO-GEI, F., 1961. Descripción de dos tremátodos de un marsupial de la República de Costa Rica y un catálogo de los tremátodos que parasitan a Marsupialia Illiger, 1811. Ann. Esc. Nac. Cien. Biol, $10: 45-86$.

CANARIS, A. G., 1971. Some Microphallids collected in Kenya. Parasitol., 62 :53-61.

DEBLOCK, S., 1973. Contribution à l'étude des Microphallidae Travassos, 1920 (Trematoda) XXVII. Ann. Parasit. Hum. comp., 48 :543-557.

HUNTER, W. S. \& VERNBERG, W. B, 1953. Pseudospelotrema ammospizae sp. nov. (Trematoda: Microphallidae) from the seaside sparrow Ammaspiza maritime macgillivraii (Audubon) J. Parasit., $39: 84-87$.

ODENING, K., 1963. Ein neuer typ von trematoden der vogelniere und andere Brasilianische trematoden aus der Schmucktangare. Z. Parasitenk., 23 :504-515.

PRICE, E. W., 1932. Trematode parasites of marine mammals. Proc. Nat. Mus., 81 :1-67.

YAMAGUTI, S., 1971. Synopsis of digenetic trematodes of vertrebates, I :1-1074, I1 :1-349. Keigaku Publishing Co. Tokyo, Japan. 